\title{
Finančné hospodárenie mesta Košice v kontexte pandémie Covid-191
}

\section{Financial management of the city of Košice in the context of the Covid-19 pandemic}

\author{
JUDr. Anna Vartašová, PhD. - Ing. Karolína Červená, PhD. \\ DOI https://doi.org/10.33542/SCD21-0043-1-29
}

\begin{abstract}
Abstrakt
Autorky sa vo svojom príspevku zamerali na vplyv opatrení v súvislosti s pandémiou (Covid19) a ich dopadom na finančné hospodárenie územnej samosprávy na príklade mesta Košice, s akcentom na zmenu príjmov a zmenu vo výdavkovej časti rozpočtu. Ciel'om autoriek bolo na základe vlastnej analýzy a komparácie vyhodnotit' dopady pandémie na rozpočet mesta Košice s využitím dostupných údajov, a taktiež aj parciálnych výsledkov, ktoré boli získané v rámci predchádzajúceho vlastného výskumu.
\end{abstract}

\section{Kl’účové slová:}

územná samospráva, rozpočet, finančné hospodárenie, pandémia Covid-19, mesto Košice

\begin{abstract}
In their contribution, the authors focused on the impact of the measures in connection with the pandemic (Covid-19) and their influence on the financial management of local government on the example of the city of Košice with emphasis on changes in revenues and expenditures. The authors aimed to evaluate the effects of the pandemic on the budget of the city of Košice based on the analysis and comparison, using the acquired data as well as partial results obtained within their previous research.
\end{abstract}

Keywords:

local government, budget, financial management, Covid-19 pandemic, City of Košice

JEL kód: H71

\section{ÚVOD}

Vláda SR vyhlásila odo dňa 12. marca 2020 na celom území SR mimoriadnu situáciu v súvislosti s rizikom šírenia ochorenia Covid-19 na základe uznesenia Vlády Slovenskej republiky č. 111 zo dňa 11. marca 2020 a následne, počas druhej vlny pandémie, od 1. októbra

\footnotetext{
${ }^{1}$ Táto práca vznikla v rámci riešenia projektu VEGA 1/0214/21 a projektu VEGA 1/0151/18.
} 
2020, došlo k vyhláseniu núdzového stavu na celom území $\mathrm{SR}^{2}$, čo malo priame aj nepriame negatívne dopady na ekonomiku celého štátu, územnú samosprávu nevynímajúc.

K realizácii štátnych/vládnych opatrení v súvislosti s riešením pandemickej situácie bolo potrebné použit' verejné financie, čo má dopad/vplyv nie len na štátny rozpočet, ale aj na rozpočty územnej samosprávy. Skúmanie priamych, ale aj nepriamych efektov realizovaných opatrení, považujeme za východisko hl'adania variantných riešení v obdobných situáciách, s ciel’om minimalizácie negatívnych dôsledkov vzniknutej „rozpočtovej krízy“ územnej samosprávy (obcí/miest) na Slovensku.

Autorky s využitím komparácie a analýzy, na príklade mesta Košice, prezentujú skutočné a predpokladané finančné dopady opatrení prijatých v dôsledku pandémie Covid-19 na rozpočet jednotiek územnej samosprávy (obcí/miest) a zároveň poukazujú na finančnú závislost' samosprávy na podielových daniach, ako to vyplýva $\mathrm{z}$ ich predchádzajúceho výskumu ${ }^{3}$ i z prác iných autorov ${ }^{4}$.

\section{FINANCOVANIE OBCÍ V SR}

Jedným z charakteristických znakov obce na Slovensku je finančná autonómia, ktorej súčast' tvorí aj autonómia daňová (t. j. samostatnost' pri rozhodovaní o zavedení a vyberaní miestnych daní), pričom jej základom je ústavný poriadok ${ }^{5}$. Systém financovania obcí v SR je založený na ústavnom princípe, že obce financujú svoje potreby predovšetkým z vlastných príjmov, ako aj zo štátnych dotácií a zákon ustanoví, ktoré dane a poplatky sú prijmom obce (čl. 65 ods. 2 ústavy), čo d'alej rozvíja zákon č. 369/1990 Zb. o obecnom zriadení v znení neskorších predpisov $\mathrm{v} \S 7$ ods. 1 a 2 (obec financuje svoje potreby predovšetkým z vlastných

\footnotetext{
${ }^{2}$ Uznesením vlády č. 587 k návrhu na vyhlásenie núdzového stavu podla čl. 5 ústavného zákona č. 227/2002 Z. z. o bezpečnosti štátu $\mathrm{v}$ čase vojny, vojnového stavu, výnimočného stavu a núdzového stavu $\mathrm{v}$ znení neskorších predpisov (publikované ako 268/2020 Z. z.).

${ }^{3}$ ROMÁNOVÁ, A., ČERVENÁ, K. Current System of Funding of Local Self-Government in Slovakia and its Challenges, Financial Law Review, vol. 2, 2017, no. 4, p. 54; VARTAŠOVÁ, A., ČERVENÁ, K. Podatki lokalne - źródlo finansowania samorzadu lokalnego na Slowacji. In Regulacje prawa finasów publicznych i prawa podatkowego: podsumowanie stanu obecnego i dynamika zmian. Varšava: Wolters Kluwer, 2020, s. 673; VARTAŠOVÁ, A. Uplatňovanie inštitútu miestnych daní v krajinách V4. In INTERPOLIS '20. Banská Bystrica: Vydavatel'stvo Univerzity Mateja Bela v Banskej Bystrici - Belianum, 2020, s. 500-508; VARTAŠOVÁ, A., ČERVENÁ, K. Views on Quality of Tax Regulation in the Slovak Republic (Focused on Real Property Taxation). Praha: Leges, 2019, s. 48.

${ }^{4}$ PAPCUNOVÁ, V., HUDÁKOVÁ, J., ŠTUBŇOVÁ, M., URBANÍKOVÁ, M. Revenues of Municipalities as a Tool of Local Self-Government Development (Comparative Study), Administrative Sciences, vol. 10, 2020, no. 4, pp. 101; BUJŇÁKOVÁ, M. Finančné problémy fungovania obcí a miest v Slovenskej republike a možnosti ich riešenia. In: Zagadnienia bezpieczeństwa i porzadku publicznego $w$ jednostkach samorzadu terytorialnego. Rzeszów: RS Druk Rzeszów, 2018, pp. 580-590. VAVROVÁ, K. Miestne dane v súvislosti s udržatel’nost'ou ich výberu $=$ Local Taxes Related to the Sustainability of their Choice. In: Markovič, P., Tóth, M. (eds.) Ekonomika, financie a manažment podniku - 2017. Bratislava: Vydavatel'stvo EKONÓM, 2017, s. 740; VERNARSKÝ, M. (2014) Finančná autonómia územnej samosprávy ako predpoklad samostatnosti v komunálnej normotvorbe. In: Teória a prax komunálnej normotvorby. Košice: P. J. Šafárik University in Košice, s. 76-82.

${ }^{5}$ LIPTÁKOVÁ, K. Kompetencie miestnej samosprávy a jej normotvorba v kontexte miestnych daní na Slovensku. In: Bratislavské právnické fórum 2018. Bratislava: Univerzita Komenského, 2018, s. 58. Totožne: VERNARSKÝ, M. Normotvorba obce vo veciach miestnych daní. In: Územná samospráva a tvorba práva. Košice: Univerzita Pavla Jozefa Šafárika v Košiciach, 2015, s. 23.
} 
príjmov $^{6}$, dotácií zo štátneho rozpočtu a z d'alšich zdrojov, pričom na plnenie svojich úloh môže použit' návratné zdroje financovania a prostriedky mimorozpočtových peňažných fondov).

Tieto zdroje špecifikuje zákon č. 583/2004 Z. z. o rozpočtových pravidlách územnej samosprávy a o zmene a doplnení niektorých zákonov v znení neskorších predpisov. V zmysle $\S 5$ tohto zákona sú príjmami rozpočtu obce výnosy miestnych daní a poplatkov, nedaňové prijmy z vlastníctva a z prevodu vlastnictva majetku obce a z činnosti obce a jej rozpočtových organizácií, úroky a iné príjmy z finančných prostriedkov obce, sankcie za porušenie finančnej discipliny uložené obcou, dary a výnosy dobrovolných zbierok v prospech obce, podiely na daniach v správe štátu (tieto predstavujú v zmysle zákona vlastné príjmy), dotácie zo štátneho rozpočtu na úhradu nákladov preneseného výkonu štátnej správy a dotácie zo štátnych fondov, d'alšie dotácie zo štátneho rozpočtu, účelové dotácie z rozpočtu vyššieho územného celku alebo z rozpočtu inej obce na realizáciu zmlúv podl'a osobitných predpisov, prostriedky z Európskej únie a iné prostriedky zo zahraničia poskytnuté na konkrétny účel, iné príjmy ustanovené osobitnými predpismi. Obec d'alej môže na plnenie svojich úloh použit' aj prostriedky mimorozpočtových peňažných fondov, prostriedky získané z rozdielu medzi výnosmi a nákladmi z podnikatel’skej činnosti po zdanení, návratné zdroje financovania, združené prostriedky.

Výdavkami obecného rozpočtu v zmysle $§ 7$ zákona o rozpočtových pravidlách územnej samosprávy sú záväzky obce vyplývajúce z plnenia povinností ustanovených osobitnými predpismi, výdavky na výkon samosprávnych pôsobností obce a na činnost' rozpočtových organizácii a príspevkových organizácii zriadených obcou, výdavky na úhradu nákladov preneseného výkonu štátnej správy, výdavky spojené so správou, údržbou a zhodnocovaním majetku obce a majetku iných osôb, ktorý obec uživa na plnenie úloh podl'a osobitných predpisov, s možnostou uhrádzania výdavkov spojených s údržbou a zhodnocovaním majetku, ktorého vlastník alebo správca nie je známy a zároveň je využivaný obyvatelmi obce na verejný účel, záväzky vzniknuté zo spolupráce s inou obcou alebo s vyšším územným celkom, prípadne s d'alšimi osobami na zabezpečenie úloh vyplývajúcich z pôsobnosti obce vrátane záväzkov vzniknutých zo spoločnej činnosti, výdavky vyplývajúce z medzinárodnej spolupráce obce, úroky z prijatých úverov, pôžičiek a návratných finančných výpomocí, výdavky súvisiace $s$ emisiou cenných papierov vydaných obcou a na výdavky na úhradu výnosov z nich, iné výdavky ustanovené osobitnými predpismi.

Vzhl'adom na vyššie zmienený ústavný princíp, to, ktoré druhy príjmov zákon o rozpočtových pravidlách územnej samosprávy považuje za vlastné príjmy a pomer jednotlivých zložiek príjmov (vid' graf č. 1), je zjavné, že tento ústavný princíp nie je celkom naplnený ${ }^{7}$.

\footnotetext{
${ }^{6}$ Toto štátom rešpektované a garantované právo samosprávneho celku na vlastné finančné zdroje, ktoré býva označované ako finančná autonómia samosprávneho celku, patrí spolu s vlastnou právotvorbou, resp. v širšom vyjadrení normotvorbou k základným atribútom autonómie územnej samosprávy. MOLITORIS, P. Princípy finančnej normotvorby územnej samosprávy. In: Teória a prax verejnej správy. Košice: Univerzita Pavla Jozefa Šafárika v Košiciach, 2013, s. 197.

${ }^{7}$ Pozri viac ROMÁNOVÁ, A., ČERVENÁ, K. Current System of Funding of Local Self-Government in Slovakia and its Challenges. In Financial Law Review, 2017, vol. 2, no. 4, s. 47.
} 
Graf 1. Podiely jednotlivých príjmov rozpočtov obcí 2008-2020

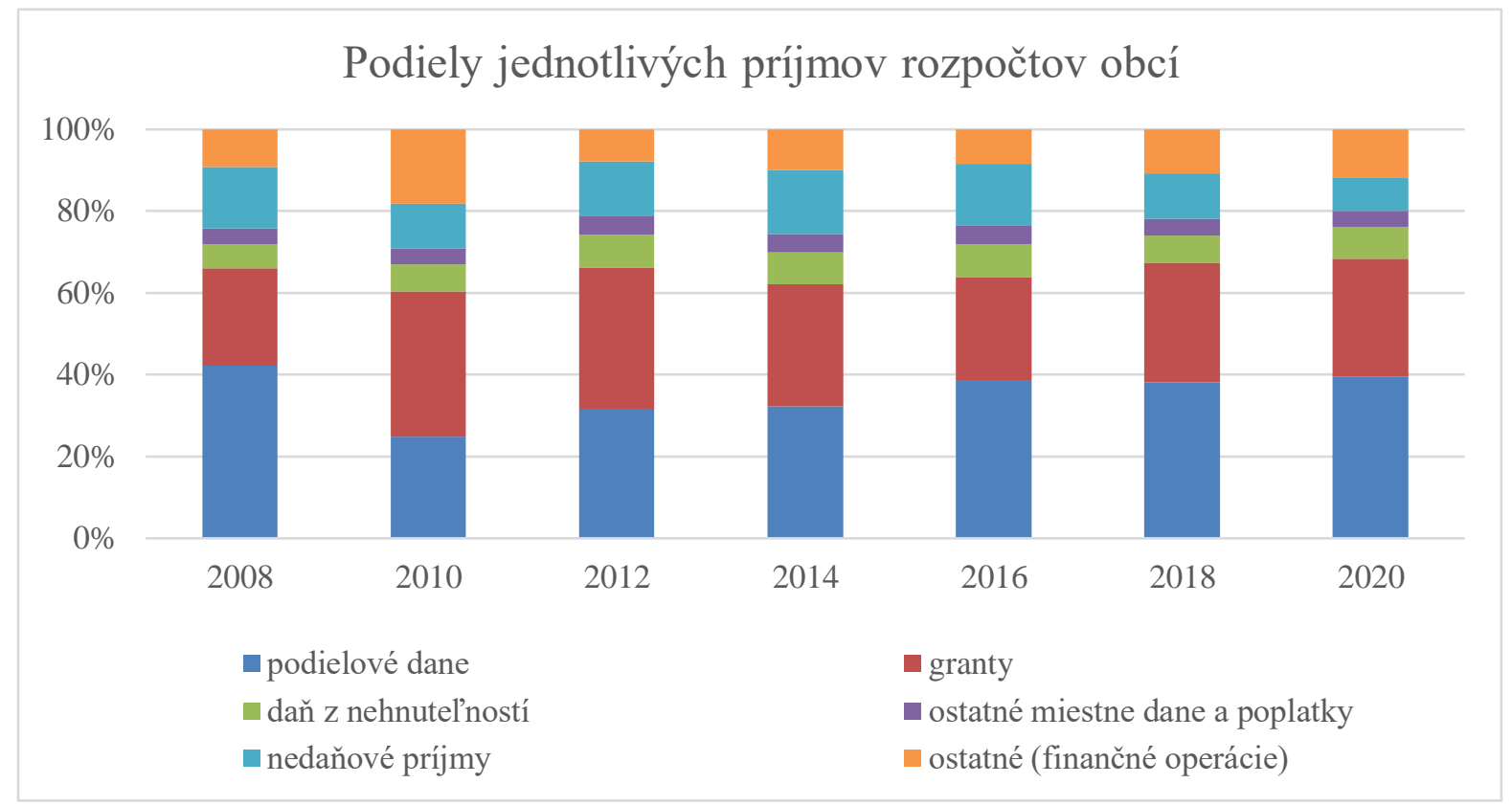

Zdroj: vlastné spracovanie podl'a údajov MF SR a Vartašová, A., Červená, K. Podatki lokalne - źródlo finansowania samorzadu lokalnego na Slowacji. In Regulacje prawa finasów publicznych i prawa podatkowego: podsumowanie stanu obecnego i dynamika zmian, s. 673.

\section{OPATRENIA MESTA KOŠICE V ROKU 2020}

Mesto Košice, ako druhá najväčšia mestská aglomerácia v $\mathrm{SR}^{8}$, je obcou so statusom mesta, ktorá plní zároveň úlohy krajského mesta a je sídlom Košického samosprávneho kraja. Postavenie mesta a jeho samospráva sú upravené zákonom č. 401/1990 Zb. o meste Košice v znení neskorších predpisov. Mesto samotné je rozdelené na 22 mestských častí, na ktoré môže štatútom preniest' výkon niektorých samosprávnych pôsobností určených obci osobitnými predpismi (§ 17 ods. 1 štatútu). Mesto a mestské časti samostatne hospodária za podmienok ustanovených zákonom, štatútom a d’alšími predpismi, s vlastným a zvereným majetkom a s vlastnými a zverenými finančnými prostriedkami a samostatne pripravujú a schvalujú svoj rozpočet a záverečný účet (\$ 36 štatútu).

V súvislosti s vyhláseným mimoriadnej situácie od 12. marca 2020 a s vyhlásením núdzového stavu na celom území SR od 1. októbra 2020, mesto Košice počas tohto obdobia prijalo viaceré (nadväzujúce) opatrenia na zamedzenie šírenia prenosu koronavírusu, a to sociálneho, zdravotného či ekonomického charakteru. Prvý rozsiahlejší súbor opatrení bol prijatý na základe uznesení z XIII. Mimoriadneho zasadnutia mestského zastupitel'stva (26. marca 2020), kedy:

\footnotetext{
${ }^{8}$ VARTAŠOVÁ, A., ČERVENÁ, K. The development of real property tax - the case of city of Košice. In Financial Law Review. ISSN 2299-6834. Roč. 20, č. 4 (2020), s. 86.
} 
- bola vyhlásená dobrovol'ná zbierka „Pomoc pre jednotlivcov a rodiny v Košiciach na zmiernenie dopadov opatrení proti šíreniu ochorenia COVID-19“ (uznesenie č. 374);

- bol primátor mesta Košice poverený opätovne listom požiadat’ predsedu vlády o odpustenie zostatku návratnej finančnej výpomoci vo výške 15,2 mil. EUR vyplývajúceho zo Zmluvy o návratnej finančnej výpomoci č. MF/014236/2014-442 zo dňa 09. júla 2014 (uznesenie č. 374);

- bolo odsúhlasené prerušenie prevádzkovania parkovacích miest v zóne plateného parkovania ${ }^{9}$ podl'a VZN mesta Košice č. 157 o dočasnom parkovaní motorových vozidiel na vymedzenom území mesta Košice v znení neskorších predpisov v prípade podstatného obmedzenia alebo vylúčenia prevádzkovania mestskej hromadnej dopravy ${ }^{10}$ (uznesenie č. 374) pričom tento režim bol ukončený s účinnost'ou od 1. júna 2020 (uznesenie č. 390);

- bol upravený rozpočet mesta (prevod z rezervného fondu vo výške 2,4 mil. EUR na opatrenia $\mathrm{v}$ dôsledku pandémie Covid-19 11 a presun plánovanej podpory v sume 100 tis. EUR pre Košická aréna, o. z. na dotácie podl’a VZN č. 190 pre poskytovatel’ov sociálnych služieb);

- sa schválilo zvýšenie hranice dôchodku pre priznanie účelového finančného príspevku na stravovanie dôchodcov v období platnosti mimoriadnych opatrení v dôsledku pandémie Covid-19 na obdobie od 1. apríla 2020 do 30. júna 2020 zo 415,00 EUR na 450,00 EUR, na základe ktorého malo cca 15.000 seniorov možnost' za zvýhodnených podmienok využit' donášku obedov (príspevok 1 EUR za jedlo a 1 EUR za dopravu denne po predložení potvrdenia o nákupe jedla príslušnej mestskej časti), nakol'ko o. i. Stredisko sociálnej pomoci mesta Košice na Garbiarskej, od piatka 13. marca pozastavilo výdaj a poskytovanie obedov pre seniorov z mestských častí (uznesenie č. 376);

- sa pozastavila účinnost' uznesenia MZ č. 58 zo dňa 14. februára 2019, ktorým sa schválilo navýšenie platu primátora o 40\%, a to od 1. apríla 2020 do 31. decembra 2020, na základe čoho poberal primátor plat len v minimálnej výške ustanovenej zákonom (4.347 EUR v hrubom), a to na návrh primátora mesta Košice (uznesenie č. 377);

- sa predížila platnost' časového cestovného lístka pre mestskú hromadnú dopravu na 30 dní, 90 dní, 180 dní a 365 dní o d’alších 60 dní, pokial' bol platný v období od 9. marca 2020 0:00 hod. do 31. marca 2020 24:00 hod, pričom najprv bolo schválené, že predíženie platnosti o d'alších 60 dní nastane v d'alší mesiac po mesiaci, v ktorom bola ukončená mimoriadna situácia (uznesenie č. 378), následne však bolo toto posunuté začatie plynutia predíženej doby platnosti s účinnost'ou od 1. júna 2020 zrušené (uznesenie č. 402 zo zasadnutia zo dňa 28. mája 2020) - toto opatrenie sa týkalo takmer 53 tis. oprávnených cestujúcich, ktorí v období od 9. marca do 31. marca mali zakúpené časové predplatné lístky a bolo zavedené ako čiastočná kompenzácia nižšieho počtu prevádzkovaných liniek a spojov pre cestujúcich v MHD, ktorej prevádzka po zatvorení škôl, úradov, verejných

\footnotetext{
${ }^{9}$ Zároveň sa vyzývali súkromní prevádzkovatelia parkovacích miest na území mesta Košice, aby za účelom zabránenia šírenia ochorenia Covid-19 tiež dočasne prerušili prevádzkovanie parkovacích miest za odplatu.

${ }^{10}$ Ku ktorému došlo od 14. marca 2020.

${ }^{11} \mathrm{~V}$ tom zahrnuté: civilná ochrana a s tým súvisiace výdavky (nákup ochranných zdravotníckych pomôcok a podobne): 1.000.000 EUR; sociálna výpomoc a s tým súvisiace výdavky: 1.400.000 EUR.
} 
inštitúcií a niektorých obchodných prevádzok od 16. marca bola vo väčšine liniek prevádzkovaná v tzv. víkendovom režime (redukcia spojov o cca 40\%);

- bol poverený primátor poskytovaním niektorých dotácií počas mimoriadnej situácie za účelom ochrany zdravia (doplnením „§ 129a Prechodné ustanovenie o poskytovaní dotácií z dôvodu mimoriadnej situácie do štatútu mesta Košice: v období od 1. apríla 2020 do 30. júna 2020 primátor rozhoduje o poskytnutí dotácie podl'a § 118 ods. 1 do výšky 5.000 EUR, ak účelom dotácie je ochrana zdravia obyvatel'stva a ochrana zdravia pracovnikov v oblasti sociálnych služieb a zdravotníctva (uznesením č. 375), následne opakovane na obdobie od 26. októbra 2020 do 31. marca 2021 (uznesením č. 513 z pokračovania XIX. zasadnutia Mestského zastupitel'stva v Košiciach zo dňa 20. októbra 2020).

Ďalším opatrením na základe uznesenia z XIV. Mimoriadneho zasadnutia mestského zastupitel'stva (29. apríla 2020) bolo zabezpečenie úverových prostriedkov na preklenutie časového nesúladu medzi príjmami a výdavkami v rozpočtovom období 2020 - $2021 \mathrm{v}$ súvislosti s mimoriadnou situáciou šírenia ochorenia Covid-19 (schválenie úveru vo výše 15.000.000 EUR od V̌šobecnej úverovej banky, a.s., a dočasné krátenie podielu dane z príjmov fyzických osôb pre mestské časti z dôvodu solidarity a boja proti pandémii Covid-19 za apríl, máj a jún 2020 priamo úmerné reálnemu výpadku podielovej dane pre mesto Košice za daný mesiac) (uznesenie č. 382).

Dňa 28. mája 2020 sa konalo XV. Zasadnutie mestského zastupitel'stva, kde bolo odsúhlasené oslobodenie od dane za užívanie verejného priestranstva na účely umiestnenia vonkajšieho sedenia od 1. júna 2020 do 31. decembra 2020 (uznesenie č. 400) a reštrukturalizácia úverov (zámer ukončit’ Zmluvu o úvere č. 000437/CORP/2019 s UniCredit Bank Czech Republic and Slovakia, a.s. zo dňa 21. novembra 2019, a schválenie prijatia dlhodobého úveru od Prima banka Slovensko, a.s. vo výške 10.000.000 EUR s lehotou splatnosti do 31. decembra 2030 na financovanie kapitálových výdavkov s čerpaním v rokoch 2020 - 2022 a po predchádzajúcom súhlase Mestského zastupitel’stva v Košiciach na financovanie bežných výdavkov s čerpaním v rokoch 2020 - 2021) (uznesenie č. 401).

Výsledkom pokračovania XIX. Zasadnutia mestského zastupitel'stva v Košiciach konaného dňa 19. októbra 2020 bolo kompenzačné opatrenie pre rezidentov, ktorí v dôsledku zrušenia platenia parkovného $\mathrm{v}$ meste mali obmedzené využitie predplatených rezidentských parkovacích kariet, a to tak, že držitel' parkovacej karty mal nárok na vydanie novej bezplatnej parkovacej karty rovnakej kategórie na dobu, ktorej dížka je zhodná s počtom dní, počas ktorých trvala platnost' parkovacej karty v období od 1. apríla 2020 do 31. mája 2020, ak držitel' parkovacej karty bude spĺn̆at' podmienky na jej vydanie podl’a VZN mesta Košice č. 157 o dočasnom parkovaní motorových vozidiel na vymedzenom území mesta Košice. Prvý deň platnosti novej parkovacej karty nadväzuje na posledný deň platnosti parkovacej karty, ktorá bola platná ku dňu 15. novembra 2020, alebo d’alšej zakúpenej parkovacej karty. Ak postup podl'a predchádzajúcej vety nebol možný, prvý deň platnosti novej parkovacej karty mal určit' 
prevádzkovatel' na základe požiadavky držitel'a predchádzajúcej parkovacej karty tak, že doba platnosti novej parkovacej karty mala uplynút' najneskôr 31. januára $2021^{12}$ (uznesenie č. 506).

Na XX. Mimoriadnom zasadnutí mestského zastupitel'stva v Košiciach dňa 16. novembra 2020 bola odsúhlasená 5. zmena Programového rozpočtu mesta Košice na rok 2020 (zníženie bežných príjmov o vyše 14 mil. EUR a zvýšenie príjmových finančných operácií o návratnú finančnú výpomoc - kompenzáciu výpadku podielu daní z príjmov fyz. osôb vo výške 5.345.256 EUR, zníženie bežných výdavkov o takmer 6 mil. EUR, zníženie kapitálových výdavkov o takmer 3 mil. EUR a zníženie výdavkových finančných operácií o vyše 800 tis. EUR (uznesenie č. 558).

Prijímané boli i d’alšie opatrenia - od 7. marca 2020 boli pozastavené všetky kultúrne, spoločenské a športové podujatia organizované mestom, d’alej, najmä od 13. marca 2020, sa obmedzovali stránkové dni a úradné hodiny pre verejnost' na magistráte mesta Košice a verejnost' mala po isté obdobie od 13. marca 2020 zakázaný prístup do kancelárií Magistrátu mesta Košice s výnimkou prízemia, ako aj do mestských podnikov, pričom väčšina zamestnancov mesta, mestských podnikov a d’alších inštitúcií v zriad'ovatel'skej pôsobnosti mesta Košice mala nariadenú prác z domu, zatvorilo sa ZOO (do 6. mája), od 14. marca 2020 prešiel Dopravný podnik mesta Košice na víkendový režim s redukciou vypravených vozidiel zo 172 denne na $86^{13}$, od 16. marca sa zatvárali detské ihriská a športoviská. Začiatkom marca sa tiež prerušilo vyučovanie na všetkých základných a materských školách v zriad'ovatel'skej pôsobnosti mesta Košice a pozastavená bola aj činnost' školských klubov a centier vol'ného času ${ }^{14}$ ako aj komunitných centier ${ }^{15}$. Od 13. marca sa obmedzil prístup na Verejný cintorín a do Krematória na nevyhnutné úkony, pričom tieto boli od 19. marca uzatvorené úplne s výnimkou troch dní medzi 1. a 3. aprílom, opätovne boli otvorené od 22. apríla. Od 11. mája sa postupne začalo s otváraním zatvorených detských ihrísk a športovísk. Vysoké náklady však spôsobovalo pravidelné čistenie a dezinfikovanie postupne otváraných a sprístupňovaných verejnosti prístupných miest.

Ďalšia etapa opatrení nasledovala od októbra, počas druhej vlny pandémie najmä v súvislosti s vyhláseným núdzovým stavom. Mesto zriad'ovalo odberové miesta na bezplatné antigénové testovanie na ochorenie Covid-19 a realizovalo jednotlivé etapy celoplošného testovania antigénovými testami nariadeného štátom. V októbri 2020 mesto Košice v areáli Bytového podniku mesta Košice (BPMK, Južné nábrežie) uskutočnilo rekonštrukciu bývalých administratívnych priestorov tak, aby ich mohli využívat' zamestnanci nemocníc počas pobytu

\footnotetext{
12 Mesto Košice plánovalo zaviest' aj úl'avy na dani za užívanie verejného priestranstva pre taxislužby $\mathrm{s}$ vyhradenými parkovacími miestami nachádzajúcimi sa v centrálnej mestskej zóne, ktoré v dôsledku opatrení pre zamedzenie širenia koronavírusu nemohli poskytovat’ svoje služby (celkom 51 dní). Tento návrh však schválený nebol.

${ }^{13} \mathrm{~V}$ apríli bol evidovaný pokles tržieb DPMK o cca $80 \%$.

${ }^{14} \mathrm{~S}$ čím súviselo pozastavenie prijímania príspevkov za pobyt dietat'a v materskej škole, na činnost’ školského klubu detí a na krúžkovú činnost' centra vol'ného času platených rodičmi.

${ }^{15}$ Boli úplne uzavreté od 16. marca 2020, v obmedzenom režime boli otvorené od 1. mája 2020 a v plnom režime od 1. júla 2020.
} 
v karanténe. Od 2. novembra 2020 mesto Košice vyčlenilo mestským častiam cca 228 tis. EUR zo svojho rezervného fondu na kompenzáciu nákladov spojených s organizáciou víkendového celoplošného testovania (á 18.000 EUR pre osem vel'kých mestských častí a 6.000 EUR d’alším štrnástim malým mestským častiam), najmä z dôvodu časového sklzu v refundácii nákladov štátom, ktoré v danom čase neboli preplatené ešte ani za obdobie prvej vlny pandémie. Výrazné obmedzenia sa dotkli podujatí aj počas obdobia Vianoc.

\section{FINANČNÉ HOSPODÁRENIE MESTA KOŠICE V ROKU 2020}

Dopad pandémie Covid-19 mal vplyv nie len na výdavkovú čast' rozpočtu ale aj na príjmovú. Z výsledkov analýzy a komparácie údajov zo záverečných účtov mesta Košice vyplýva, že v roku 2020 došlo k poklesu celkových príjmov (v porovnaní s rokom 2019 o 6.128.256,34 EUR a rokom 2018 o 18.115.244,38 EUR) aj k poklesu celkových výdavkov (o 7.379.403,58 EUR v porovnaní s rokom 2019 a o 13.885.943,95 EUR v porovnaní s rokom 2018).

Tabul'ka 1. Prehl'ad príjmov a výdavkov mesta Košice za roky 2018 - 2021 (v EUR)

\begin{tabular}{|c|r|r|r|r|}
\hline \multicolumn{1}{|c|}{ Roky } & $\mathbf{2 0 1 8}$ & \multicolumn{1}{c|}{$\mathbf{2 0 1 9}$} & \multicolumn{1}{c|}{$\mathbf{2 0 2 0}$} & \multicolumn{1}{c|}{$\begin{array}{c}\mathbf{2 0 2 1} \\
\text { (predpoklad) }\end{array}$} \\
\hline Celkové príjmy & $228.789 .236,78$ & $216.802 .248,74$ & $210.673 .992,40$ & 253.126 .333 \\
\hline Bežné príjmy & $174.048 .923,64$ & $185.952 .234,34$ & $196.772 .642,49$ & 205.669 .188 \\
\hline Daňové príjmy & $126.667 .931,93$ & $133.888 .972,21$ & $138.500 .361,09$ & 148.714 .907 \\
\hline Daň z nehnutel’ností & $22.482 .729,50$ & $21.592 .461,89$ & $26.556 .595,87$ & 38.500 .000 \\
\hline Kapitálové príjmy & $36.901 .676,24$ & $23.121 .355,51$ & $678.778,36$ & 11.087 .793 \\
\hline Fin. oper. príjmy & $17.838 .636,90$ & $7.728 .658,89$ & $13.222 .571,55$ & 36.369 .352 \\
\hline Celkové výdavky & $220.623 .461,62$ & $214.116 .921,25$ & $206.737 .517,67$ & 252.126 .333 \\
\hline Bežné výdavky & $159.729 .231,39$ & $179.740 .754,21$ & $190.193 .544,15$ & 209.314 .929 \\
\hline Kapitálové výdavky & $54.712 .216,33$ & $12.257 .074,38$ & $9.196 .001,43$ & 38.115 .404 \\
\hline Fin. oper. výdavky & $6.182 .013,90$ & $22.119 .092,66$ & $7.347 .972,09$ & 4.696 .000 \\
\hline
\end{tabular}

Zdroj: vlastné spracovanie podl’a údajov zo záverečných účtov mesta Košice 2018-2020 a návrhu rozpočtu mesta Košice na rok 2021 (po 4. zmene).

Opatrenia prijímané v priebehu roku 2020, najmä jednotlivé úpravy rozpočtu a úkony smerujúce $\mathrm{k}$ prevzatiu úverov boli podmienené neistotou ohl'adom predpokladaného výpadku prímov mesta ${ }^{16}$ a tým ohrozením finančnej likvidity. Už v 1. polroku 2020 sa vo finančnom hospodárení mesta Košice prejavili dopady krízy, kedy o. i. došlo aj k poklesu príjmov z podielových daní, ked’že bol poukázaný nižší podiel dane z príjmov fyzických osôb o 3,3 mil. EUR oproti pôvodne schválenému rozpočtu verejnej správy. Celkový pokles príjmov z podielu dane z príjmov fyzických osôb v roku 2020 pre mesto Košice bol takmer vo výške 5,4 mil. EUR, pričom MF SR nahradilo tento schodok vo forme návratnej finančnej

\footnotetext{
${ }^{16}$ Už v apríli sa predpokladal výpadok príjmov z podielových daní vo výške 30 mil. EUR a d’alších 10 mil. EUR zo zníženého výberu miestnych daní a poplatkov, tiež v dôsledku výpadkov príjmov mestských podnikov.
} 
výpomoci ${ }^{17}$, ktorá je zahrnutá v príjmových finančných operáciách. Prepad príjmov v roku 2020 sa prejavil aj vo vlastných daňových a nedaňových príjmoch oproti schválenému rozpočtu, pričom pokles vlastných príjmov mesta Košice za rok 2020 bol v priemere o 17\% (t. j. o cca 11 mil. EUR $)^{18}$. Na základe uvedených skutočností bola v novembri mestským zastupitel'stvom schválená, v poradí už 5. zmena programového rozpočtu 2020, kde vo výdavkovej časti rozpočtu boli premietnuté úspory prevádzkových výdavkov, ostatných bežných a kapitálových výdavkov a finančných operácií.

Tabul'ka 2. Príjmy (v EUR) mesta Košice v roku 2020 - rozpočet a skutočnost'

\begin{tabular}{|c|c|c|c|c|}
\hline & $\begin{array}{l}\text { Schválený } \\
\text { rozpočet }\end{array}$ & $\begin{array}{l}\text { Upravený } \\
\text { rozpočet }\end{array}$ & Skutočnost' & $\begin{array}{l}\text { \% plnenia } \\
\text { pôv. rozpočtu }\end{array}$ \\
\hline celkové príj my & 225.209 .214 & 230.936 .718 & 210.673 .992 & $93,55 \%$ \\
\hline podielové dane* & 114.035 .509 & 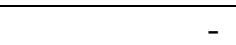 & 108.690 .253 & $95,31 \%$ \\
\hline dan̆ z nehnutel'ností & 33.000 .000 & 25.750 .000 & 26.556 .596 & $80,47 \%$ \\
\hline ostatné miestne dane a poplatky & 16.903 .194 & 14.703 .194 & 14.726 .625 & $87,12 \%$ \\
\hline zapsa & 220.000 & 220.000 & 220.083 & $100,04 \%$ \\
\hline za nevýherné hracie pristroje & 6.000 & 6.000 & 3.758 & $62,63 \%$ \\
\hline za predajné automaty & 32.000 & 32.000 & 22.276 & $69,61 \%$ \\
\hline $\begin{array}{l}\text { za vjazd do historickej časti } \\
\text { mesta }\end{array}$ & 500 & 500 & 207 & $41,40 \%$ \\
\hline za ubytovanie & 600.000 & 200.000 & 289.702 & $48,28 \%$ \\
\hline $\begin{array}{l}\text { za užívanie verejného } \\
\text { priestranstva }\end{array}$ & 750.000 & 550.000 & 551.902 & $73,59 \%$ \\
\hline $\begin{array}{l}\text { poplatok za komunálne odpady a } \\
\text { drobné stavebné odpady }\end{array}$ & 10.800 .000 & 10.200 .000 & 10.566 .656 & $97,84 \%$ \\
\hline poplatok za uloženie odpadu & 3.600 .000 & 2.600 .000 & 2.662 .006 & $73,94 \%$ \\
\hline poplatok za rozvoj & 1.000 .000 & 1.000 .000 & 515.341 & $51,53 \%$ \\
\hline nedaňové príimy & 12.852 .321 & 11.336 .671 & 10.255 .655 & $79.80 \%$ \\
\hline
\end{tabular}

Zdroj: vlastné spracovanie podl'a Záverečného účtu mesta Košice za rok 2020.

* položka podielové dane sa v rozpočte neuvádza ako samostatný údaj, napriek tomu ju považujeme v kontexte príspevku za podstatnú

V súvislosti s opatreniami týkajúcimi sa pandemickej situácie Covid-19 muselo mesto Košice financovat' viaceré činnosti a materiálne potreby, a to najmä:

\footnotetext{
${ }^{17}$ V zmluve s MF SR o poskytnutí návratnej finančnej výpomoci vo výške 5,35 mil. EUR sa Ministerstvo, na základe Uznesenia vlády z augusta 2020, zaväzuje kompenzovat výpadky dane z príjmov fyzických osôb v roku 2020, ktoré vznikli počas pandémie nového koronavírusu, čo je ale možné použit výlučne a v plnom rozsahu na financovanie výkonu samosprávnych kompetencií, teda Mesto nimi prefinancuje svoje bežné a kapitálové výdavky vrátane investícií do svojho majetku a dlžnú sumu, v 4 rovnomerných splátkach (1,336 mil. EUR), sa zaviazalo vrátit' v rokoch 2024-2027. Podmienkou poskytnutia návratnej finančnej výpomoci bolo, že dlh mesta neprekročí $50 \%$ skutočných bežných príjmov predchádzajúceho rozpočtového roka, čo mesto Košice spíña, ked’že aj po prijatí návratnej finančnej výpomoci a započítaní ostatných plánovaných úverov neprekročí dlh mesta $30 \%$ tejto hodnoty. https://www.kosice.sk/clanok/kosice-dostanu-vyse-5-3-milionovu-pozicku-z-ministerstva-financii.

18 Významné boli i straty tržieb v mestských organizáciách, najmä v DPMK, a.s. (cca 4,7 mil. EUR), v organizáciách poskytujúcich sociálne služby (Stredisko sociálnej pomoci, Psychosociálne centrum, ZOS) a ostatných organizáciách (ZOO, BPMK). Zdroj: Mesto Košice: Informácia o predbežných výdavkoch na COVID$19 z a$ obdobie 2020, I-III/2021, dostupné online: https://www.kosice.sk/mesto/samosprava/mestskezastupitelstvo/ 2018-2022/zasadnutie/27/uznesenie/630.
} 
- z časti bežných výdavkov rozpočtu 2020 (190.193.544,15 EUR), v súvislosti s mimoriadnou udalost'ou (pandémia Covid-19), boli realizované výdavky vo výške 1.352.347 EUR, a to v členení:

- Civilná ochrana a s tým súvisiace výdavky - finančné prostriedky vo výške 1.142.479 EUR boli použité najmä na zakúpenie antibakteriálnych a dezinfekčných prostriedkov, bezdotykových dávkovačov, dezinfekčných brán, ochranných pracovných pomôcok a odevov, na dezinfekciu priestorov úradu a služobných motorových vozidiel;

- Sociálna výpomoc a s tým súvisiace výdavky - finančné prostriedky vo výške $\mathbf{1 5 0 . 8 3 8}$ EUR boli použité na mimoriadnu sociálnu pomoc ohrozeným obyvatel'om mesta Košice v súvislosti s opatreniami Covid-19: mestským častiam bol poskytnutý transfer vo výške 68.373 EUR na stravovanie dôchodcov, donášku obedov, nákup a donášku potravín a liekov; výdavky vo výške 45.368 EUR boli použité na sociálne balíčky pre seniorov, l'udí bez domova a jednotlivcom a rodinám; nadáciám Oáza n.o., DORKA n.o., Arcidiecézna charita Košice boli poskytnuté finančné príspevky v celkovej výške 15.000 EUR pre l'udí bez domova a tiež transfer vo výške 22.097 EUR bol poskytnutý SSP ako refundácia vrátených finančných prostriedkov MPSVaR SR za neobsadené miesta z dôvodu zriadenia karanténneho centra;

- Dotácie podl'a VZN 190 pre poskytovatel'ov sociálnych služieb - finančné prostriedky vo výške 59.030 EUR boli poskytnuté pre poskytovatel'ov sociálnych služieb na ochranu zdravia obyvatel'stva a ochranu zdravia pracovníkov v oblasti sociálnych služieb a zdravotníctva;

- $\quad$ v rámci kapitálových výdavkov (358.136 EUR), v súvislosti s mimoriadnou udalost’ou (pandémia Covid-19), boli realizované výdavky:

- krízové ubytovanie pre marginalizované skupiny obyvatel'ov mesta Košice v areáli BPMK na Južnom nábreží v celkovej výške 199.026 EUR;

- stavebné úpravy priestorov karanténneho ubytovania $\mathrm{v}$ areáli BPMK pre zamestnancov mesta, orgánov samosprávy a organizácií zriadených mestom vo výške 44.210 EUR;

- obstaranie 5 dezinfekčných brán v celkovej výške 26.400 EUR;

- kontajnery - mobilné domy vrátane prípojok inžinierskych sietí pre karanténu klientov Arcidiecéznej charity - Charitného domu sv. Alžbety na Bosákovej ul. vo výške 57.000 EUR;

- kontajnery - mobilné domy vrátane prípojok inžinierskych sietí pre karanténu klientov zariadenia Oáza - nádej pre nový život vo výške 31.500 EUR.

- V časti finančné operácie v položke príjmy (13.222.572 EUR) bola zaúčtovaná návratná finančná výpomoc z MF SR v celkovej výške 5.345.256 EUR, ktorá bola čerpaná na výkon samosprávnych pôsobností z dôvodu kompenzácie výpadku DPFO v roku $2020 \mathrm{v}$ dôsledku pandémie Covid-19. Použitie výpomoci slúžilo na vykrytie bežných výdavkov, a to na zimnú údržbu komunikácií, čistenie komunikácií a bežnú údržbu komunikácií.

Mestu Košice bola poskytnutá dotácia na refundáciu výdavkov súvisiacich $\mathrm{s}$ mimoriadnou situáciou, $\mathrm{v}$ súvislosti $\mathrm{s}$ ohrozením verejného zdravia II. stupňa $\mathrm{z}$ dôvodu ochorenia Covid-19 vo výške 913.194 EUR (počas prvej vlny pandémie vo výške 872.916 EUR a výdavkov súvisiacich s celoštátnym testovaním v novembri 2020 vo výške $\mathbf{4 0 . 2 7 8}$ 
EUR), v rozpočte zahrnuté v položke Bežné granty a transfery (48.016.626 EUR). ${ }^{19}$ Celkový prehl'ad refundácie nákladov prezentuje tabul'ka č. 3 .

Tabul'ka 3. Refundácie nákladov mesta Košice na realizované opatrenia v rámci pandémie Covid-19 v za obdobie 2020 - marec 2021

\begin{tabular}{|c|l|r|r|r|}
\hline Rok & \multicolumn{1}{|c|}{ Opatrenia } & \multicolumn{3}{c|}{ Výdavk mesta (v EUR) } \\
\hline $\mathbf{2 0 2 0}$ & \multicolumn{1}{|c|}{ Výdavok } & \multicolumn{1}{c|}{ Refundácia } & \multicolumn{1}{c|}{ Rozdiel } \\
\hline & $\begin{array}{l}\text { Covid-19: 12. marec 2020 - 31. } \\
\text { december 2020 }\end{array}$ & 1.648 .693 & 1.186 .831 & -461.862 \\
\hline & celoštátne testovanie & 450.497 & 288.909 & -161.588 \\
\hline & sociálna oblast' & 693.889 & 0 & -693.889 \\
\hline & celkom 2020 & $\mathbf{2 . 7 9 3 . 0 7 9}$ & $\mathbf{1 . 4 7 5 . 7 4 0}$ & $\mathbf{- 1 . 3 1 7 . 3 3 9}$ \\
\hline $\mathbf{2 0 2 1}$ & & & & 0 \\
\hline & $\begin{array}{l}\text { Covid-19: mestské testovanie a } \\
\text { ostatné preventívne opatrenia }\end{array}$ & 163.562 & & -163.562 \\
\hline & celoštátny skríning & 583.665 & 984.100 & 400.435 \\
\hline & $\begin{array}{l}\text { testovanie 3. februára - 31. marca } \\
\text { 2021 }\end{array}$ & 667.995 & 1.254 .235 & 586.240 \\
\hline & sociálna oblast' & 89.410 & & -89.410 \\
\hline & celkom 2021 & $\mathbf{1 . 5 0 4 . 6 3 2}$ & $\mathbf{2 . 2 3 8 . 3 3 5}$ & $\mathbf{7 3 3 . 7 0 3}$ \\
\hline & súhrn 2020+2021 & $\mathbf{4 . 2 9 7 . 7 1 1}$ & $\mathbf{3 . 7 1 4 . 0 7 5}$ & $\mathbf{- 5 8 3 . 6 3 6}$ \\
\hline
\end{tabular}

Zdroj: Mesto Košice: Informácia o čiastočnom vyhodnotení výdavkov na záchranné práce v súvislosti s mimoriadnou situáciou vyhlásenou pre ohrozenie zdravia II. stupňa, infekčného ochorenia COVID-19, dostupné online https://www.kosice.sk/mesto/samosprava/mestskezastupitelstvo/2018-2022/ zasadnutie/27.

\section{ZÁVER}

Rok 2020 bol rokom pandémie Covid-19 a s tým súvisiacich opatrení prijímaných a realizovaných na celoštátnej ale i lokálnej úrovni, s ciel'om ochrany l'udského života a zdravia. Komplexné dopady týchto opatrení na finančné hospodárenie územnej samosprávy bude možné vyhodnotit' až po definitívnom ukončení ich platnosti a sumarizácii všetkých údajov. Napriek tomu sa autorky, s využitím analýzy a komparácie údajov a informácií uvedených $\mathrm{v}$ zozname použitých zdrojov ako aj $\mathrm{v}$ texte príspevku, pokúsili čiastkovo na príklade finančného hospodárenia mesta Košice prezentovat' niekol'ko vlastných zistení a predikcií, pričom skúmali finančné dopady priame - výdavky v súvislosti s aktuálnou situáciou a opatreniami, ale aj nepriame ako napríklad pokles príjmov v mestských podnikoch.

Primárny vplyv pandémie Covid-19 a s tým súvisiacich opatrení počas roka 2020 bol viditel'ný už aj v potrebe opakovanej úpravy rozpočtu mesta (celkovo šest' krát), ktoré sa týkali výdavkovej ako aj príjmovej. Zmeny v štruktúre rozpočtu boli vyvolané nie len vlastnými sekundárnymi opatreniami prijímanými mestom Košice (poskytovanie sociálne pomoci, prerušenie výberu parkovného a predíženie platnosti predplatených rezidentských parkovacích

${ }^{19}$ Zdroj: Hodnotiaca správa programového rozpočtu mesta Košice k 31.12.2020. 
kariet, oslobodenie od dane z verejného priestranstva na účel umiestnenia vonkajšieho sedenia, znižovanie pôvodne plánovaných bežných i kapitálových výdavkov, zriadenie karanténneho centra, uzavretie ZOO, úplné zrušenie, resp. obmedzenie kultúrnych, charitatívnych, športových a vzdelávacích aktivít a pod.), ale najmä primárnymi opatreniami prijímanými na úrovni štátu, a to vyhlásením mimoriadnej situácie, núdzového stavu, zákazu vychádzania, zákazu prevádzkovania niektorých obchodov, prevádzok, poskytovania služieb, povinnost’ami zabezpečit' testovanie na ochorenie Covid-19 samosprávou a pod., ale aj úpravou legislatívy v kontexte zákona č. 67/2020 Z. z. o niektorých mimoriadnych opatreniach vo finančnej oblasti $v$ súvislosti so širením nebezpečnej nákazlivej l’udskej choroby COVID-19 v znení neskoršich predpisov, a to prerušením rôznych konaní (napr. odvolacie konania), odpustením zmeškaných lehôt, nemožnost'ou vymáhania nedoplatkov, odložením splatnosti, znížením už vyrubeného poplatku a d'alšími opatreniami.

Zo záverečného účtu mesta Košice za rok 2020 sme identifikovali záporné rozdiely (uvádzame zaokrúhlene) rozpočet vs. skutočnost' v rámci rozpočtových položiek tvoriacich sumárne celkový príjem a celkové výdavky, a to:

\section{Dopady na príjmovú čast' rozpočtu mesta Košice:}

- $\quad$ výpadok daňových príjmov celkovo o 10,8 mil. EUR (v tom: pokles dane z nehnutel'ností o 6,4 mil. EUR ${ }^{20}$, pokles výnosu dane $\mathrm{z}$ príjmov, ziskov a kapitálového majetku ${ }^{21}$ a pokles príjmov z ostatných miestnych daní a poplatkov ${ }^{22}$ rovnako o 2,2 mil. EUR),

- zníženie nedaňových príjmov (príjmy z podnikania a vlastníctva majetku, administratívne poplatky, úroky) o 2,6 mil. EUR,

- pokles kapitálových príjmov o 3,5 mil. EUR,

- pokles príjmov z finančných operácií o 10 mil. EUR,

Čiastočná kompenzácia negatívneho vývoja celkových príjmov bola kompenzovaná $\mathrm{v}$ rámci rozpočtovej položky bežné granty a transfery kde došlo ku kladnému rozdielu, a to o 12,4 mil. EUR, pričom ale vo výsledku došlo k poklesu sumy celkových príjmov o 14,5 mil. EUR.

\section{Dopady na výdavkovú čast' rozpočtu mesta Košice:}

- pokles celkových výdavkov o 17,5 mil. EUR, z toho:

○ pokles bežných výdavkov o 3,1 mil. EUR,

○ pokles kapitálových výdavkov o 15,6 mil. EUR,

\footnotetext{
${ }^{20}$ Predovšetkým z dôvodu neuhradenia dane z nehnutel'nosti spoločnost'ou U.S. Steel, kde bolo rozhodnutie Finančným riaditel'stvom SR zrušené a vrátené správcovi dane na d’alšie konanie a rozhodnutie dňa 15 . decembra 2020, ale tiež v dôsledku nemožnosti vymáhat’ nedoplatky v zmysle $\S 11$ zákona 67/2020 Z. z. o niektorých mimoriadnych opatreniach vo finančnej oblasti v súvislosti so širením nebezpečnej nákazlivej l’udskej choroby COVID-19, teda nové exekučné konania bolo možné začat' až v priebehu novembra 2020.

${ }^{21}$ Príjem v sume 108.690.53 EUR, pochádzajúci z podielových daní (transfer zo ŠR) za rok 2020, bol takmer o 5,4 mil. EUR v porovnaní s očakávaným (rozpočtovaným) príjmom nižší, pričom z uvedenej pridelenej sumy mesto realizovalo transfer mestským častiam v celkovej sume 11.473.113 EUR.

${ }^{22} \mathrm{~V}$ tom zahrnuté: daň za psa, za nevýherné hracie prístroje, za predajné automaty, za vjazd do historickej časti mesta, za užívanie verejného priestranstva, za ubytovanie a poplatky za uloženie odpadu, za komunálne odpady a drobné stavebné odpady, za rozvoj.
} 
○ nárast výdavkov v rámci položky finančné operácie o 1,2 mil. EUR.

Kompenzácia negatívnych finančných dôsledkov opatrení nariadených štátom nebola podl'a nášho názoru zrejme realizovaná promptne, efektívne a úplne, pričom vzhl’adom na trvajúci stav ohrozenia ochorením Covid-19 sa očakáva pretrvávanie negatívnych dopadov už v minulosti prijatých opatrení alebo ah tých budúcich, ako napríklad:

- výpadok tzv. podielových daní (v sume 5.345.256 EUR), ktorý bol síce kompenzovaný návratnou finančnou výpomocou MF SR, ale až v polovici októbra 2020;

- výdavky v celkovej sume 4.297.712 EUR (z toho za rok 2020 2.793.079 EUR) na zabezpečenie opatrení (v období od 1. januára 2020 do 31. marca 2021), pričom zo ŠR SR boli mestu Košice refundované finančné prostriedky v sume 3.714.076 EUR (z toho za rok 2020 1.475.741 EUR), z čoho vyplýva, že výdavky na zabezpečenie opatrení za uvedené obdobie, boli oproti refundovaným vyššie o 583.636 EUR, pričom túto sumu muselo mesto Košice financovat' z vlastných zdrojov;

- v roku 2021 (obdobie od 1. januára 2021 do 31. marca 2021) sa taktiež prejavili negatívne dopady na príjmy mesta Košice - napríklad v DPMK, a.s. je to za sledované obdobie pokles tržieb cca o 2,5 mil. EUR, v organizáciách poskytujúcich sociálne služby cca o 60 tis. EUR, školstve cca o 150 tis. EUR, u ostatných poplatkov a platieb už viac ako o 300 tis. EUR, čo zrejme vyvolalo opätovnú potrebu úpravy rozpočtu mesta Košice v roku 2021 (doposial' bola schválená na XXIV. Zasadnutí mestského zastupitel'stva 1. júla 2021 štvrtá zmena rozpočtu mesta Košice).

Autorky na základe prezentovaných údajov, ako aj d’alších informácií predpokladajú, že uvedené skutočnosti budú mat' i dlhodobé dopady najmä v podobe zvýšenia zadlženosti či obmedzenia plánovaných činností (napr. investičných) mesta Košice, pričom takýto efekt považujú za možné potvrdenie vysokej zranitel'nosti finančnej situácie územnej samosprávy (najmä pri nepredvídaných situáciách) a jej závislosti na príjmoch poukazovaných štátom.

\section{POUŽITÁ LITERATÚRA}

1. BUJŇÁKOVÁ, M. Finančné problémy fungovania obcí a miest v Slovenskej republike a možnosti ich riešenia. In: Zagadnienia bezpieczeństwa i porzadku publicznego w jednostkach samorzadu terytorialnego. Rzeszów: RS Druk Rzeszów, 2018, pp. 580-590.

2. LIPTÁKOVÁ, Kompetencie miestnej samosprávy a jej normotvorba v kontexte miestnych daní na Slovensku. In: Bratislavské právnické fórum 2018, Bratislava: Univerzita Komenského, 2018, s. 56-66. ISBN 978-80-7160-475-4.

3. Mesto Košice. Informácia o predbežných výdavkoch na COVID-19 za obdobie 2020, I-III/2021. Dostupné online: https://www.kosice.sk/mesto/samosprava/mestskezastupitelstvo/2018-2022/zasadnutie/27/uznesenie/630. 
4. Mesto Košice. Programový rozpočet mesta Košice, záverečný účet a výročná správa. Dostupné online: https://www.kosice.sk/obcan/programovy-rozpocet-mesta-kosicezaverecny-ucet-a-vyrocna-sprava-archiv.

5. Mesto Košice. Hodnotiaca správa programového rozpočtu mesta Košice $k$ 31.12.2020. Dostupné online: https://www.kosice.sk/obcan/programovy-rozpocetmesta-kosice-zaverecny-ucet-a-vyrocna-sprava-archiv.

6. MOLITORIS, P. Princípy finančnej normotvorby územnej samosprávy. In: Teória a prax verejnej správy. Košice: Univerzita Pavla Jozefa Šafárika v Košiciach, 2013. s. 197.

7. PAPCUNOVÁ, V., HUdÁKOVÁ, J., ŠTuBŇOVÁ, M., URBANÍKOVÁ, M. Revenues of Municipalities as a Tool of Local Self-Government Development (Comparative Study), 2020, Administrative Sciences, vol. 10, no. 4, pp. 101. DOI: 10.3390/admsci10040101;

8. ROMÁNOVÁ, A., ČERVENÁ, K. Current System of Funding of Local SelfGovernment in Slovakia and its Challenges. In Financial Law Review, ISSN 22996834 , roč. 2, 2017, č. 4, s. 45-56. DOI 10.4467/22996834FLR.17.015.10333.

9. VARTAŠOVÁ, A. (2020) Uplatňovanie inštitútu miestnych daní v krajinách, V4. In INTERPOLIS '20. Banská Bystrica: Vydavatel'stvo Univerzity Mateja Bela v Banskej Bystrici - Belianum, 2020, s. 500-508. ISBN 9788055718040.

10. VARTAŠOVÁ, A., ČERVENÁ, K. The development of real property tax - the case of city of Košice. In Financial Law Review. ISSN 2299-6834, roč. 20, 2020, č. 4, s. 82-104.

11. VARTAŠOVÁ, A., ČERVENÁ, K. Podatki lokalne - źródlo finansowania samorzadu lokalnego na Slowacji. In Regulacje prawa finasów publicznych $i$ prawa podatkowego: podsumowanie stanu obecnego i dynamika zmian. Varšava: Wolters Kluwer, 2020, s. 664-675. ISBN 9788381878982.

12. VARTAŠOVÁ, A., ČERVENÁ, K. Views on Quality of Tax Regulation in the Slovak Republic (Focused on Real Property Taxation). Praha: Leges, 2019. 93 s.

13. VAVROVÁ, K. Miestne dane v súvislosti s udržatel'nost'ou ich výberu = Local Taxes Related to the Sustainability of their Choice. In: Markovič, P., Tóth, M. (eds.) Ekonomika, financie a manažment podniku - 2017, Bratislava: Vydavatel'stvo EKONÓM, 2017, s. 731-742.

14. VERNARSKÝ, M. Normotvorba obce vo veciach miestnych daní. In: Územná samospráva a tvorba práva. Košice: Univerzita Pavla Jozefa Šafárika v Košiciach, 2015, s. 22-42. ISBN 978-80-8152-384-7.

15. VERNARSKÝ, M. Finančná autonómia územnej samosprávy ako predpoklad samostatnosti v komunálnej normotvorbe. In: Teória a prax komunálnej normotvorby. Košice: P. J. Šafárik University in Košice, 2014, s. 76-82. ISBN 9788081522277. 
KONTAKT NA AUTORA

anna.romanova@upjs.sk ORCID: 0000-0002-1366-0134

karolina.cervena@upjs.sk ORCID: 0000-0003-4900-6510

Univerzita Pavla Jozefa Šafárika v Košiciach

Právnická fakulta

Kováčska 26

04075 Košice

Slovenská republika 